\title{
数值地形モデルを用いた表層崩壊危険度の予測法
}

\section{A DELINEATION METHOD FOR PROBABLE MOUNTAIN SLOPE FAILURES BY A DIGITAL LAND FORM MODEL}

\author{
沖村孝*・市川龍平** \\ By Takashi OKIMURA and Ryuhei ICHIKA WA
}

\begin{abstract}
A method for predicting surface failures which occur during heavy rainfall on granite mountain slopes is proposed by using the digital land form model that is obtained by reading altitude on a topographical map at $10 \mathrm{~m}$ grid point space. A depth of a potential failure layer is assumed at each grid point. In the layer, an infiltrated water movement from cell to cell is modeled in the study (cell is a square of the grid). Infiltrated ground water levels which show the three dimensional effects of a topographical factor in an area can be hourly calculated at every cell by the model. The safety factor of every cell is also calculated every hour by the infinite slope stability analysis method with the obtained infiltrated ground water level.

Failure potential delineation is defined here as the time when the safety factor becomes less than unity under the assumptions that the depth of the layer is $1.2 \mathrm{~m}$ and effective rainfall, $20 \mathrm{~mm} / \mathrm{hr}$, continues 50 hours. More hazardous cells are found to appear at the sites where mountain slope failures occurred in the past time.
\end{abstract}

\section{1.はじめに}

花崗岩地域で豪雨中に発生する崩壊は崩壊深さが浅い (1２ m) いわゆる表層崩壊の形態をとることが多い. これは花崗岩の風化生成物であるマサ土が基岩を薄く覆 い,このマサ土が崩壊するためである.したがって表層 崩壊の発生は, 特に地形条件の影響を強く受けるものと 考えられる. 著者らは地形条件のうち傾斜と集水面積お よびマサ土層の分布条件の三要因が表層崩壊の発生に特 に重要な要因であると考えた。これら三要因に関しては 沖村が次に述べるような結果をすでに明らかにしてい る. マサ土層の分布については, 彼は現地調査により崩 壊が多発する土層を明らかにするとともに，簡易貫入試 験により崩壊が将来発生するであろう土層が定義できる ことを示し，これを「潜在崩土層」と名付けだ!.さらに， 斜面縦断面上にこの崩土層の分布を示し，これをいくつ かのブロックよりなるものと仮定し, 多平面安定解析法 により得られる最小安全率を示す危険すべり面の位置は 過去の崩壊発生位置と一致することを示し，傾斜と土層

* 正会員 理博 神戸大学助教授 工学部付属土地造成工学 研究施設

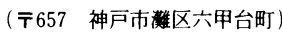

** 正会員 工修（株)パスコ大阪支社（元院生）

( ₹550 大阪市西区西本町)
分布の二要因でほぼ崩壊発生位置およびその規模が予知 できることを示した2).しかし，この手法では縦断面上 で約 $2 \mathrm{~m} こ ゙ と に$ 潜在崩土層を求める必要があり, 多く の斜面を対象とする場合にはこの調査は不可能に近いた め, 土層調査をすべき危険斜面をあらかじめ抽出する必 要があると沖村は考えた。このため彼は残る一要因であ る集水面積と傾斜の二要因を使った地形的滑動力示数 ${ }^{3}$ を採用し，この示数を数值地形モデルから求める手法を 提案した . さらに，これらの手法を組み合わせること により表層崩壊の発生位置を予知するシステムをも提案 している4).

しかし，これらの手法には以下に述べる問題点も内在 している.

1）集水面積を要因として採用しているため，一点に 集水する集水面積が設定できない平行型，尾根型斜面で は予知が行えず, 谷型斜面のみを対象としている. とこ ろが，1967 年に六甲山系で発生した崩壊では約 $26 \%$ が 谷型以外の斜面で発生している.このため,これらの斜 面で発生する崩壊をも対象とする必要がある.

2）地形的滑動力示数は，その係数，判別示数が経験 的に得られる值であるため，他地域にも適用するために は多くの地域で調査, 解析を積み重ねる必要がある. 現 在まで二，三の地域で試みた結果では，対象地域の平均 
傾斜によりその係数，示数が異なるようである51.

3）ここで用いている要因はいずれも素因であり，崩 壊の直接の原因となる誘因 (降雨) が評価されていない.

4）集水面積という要因は集水する量の大きさを表わ すが, 集水面積の形状および斜面の局所傾斜条件により， よ゙のような流量増加の変化を経るかが不明である。この ため, 降雨開始初期における安定性を考虑するためには, 集水面積以外の集水性を地形特性からさらに評価する必 要がある.

本報では，これらの問題点を解決するために新たな崩 壊予知手法を提案しようとするものである。この崩壊予 知手法も地形計测, 解析を電算機処理によって迅速, 正 確に行えるよう地形図を $10 \mathrm{~m}$ 格子間隔で数值地形モデ ル化した.この予知手法は，1）調査地域内のすべての 斜面を予知の対象とし，2）雨水の浸透により基岩面か ら形成される地下水位のみならず，これらが表土層内を 流下するプロセスを表わすモデルを作成することによ り，集水性を新たに評価し，3）この地下水位およびそ の他の地形要因, 土質要因を用いて各単位斜面 (10 m 格 子で囲まれた部分, 以後これを「セル」と称する) で有 効応力法による無限長斜面安定解析を行い, すべてのセ ルを対象にその危険度を評価する手法である.

本報では，この手法を竹平 $\mathrm{NW}$ 試験地 ${ }^{214}{ }^{41}$ に適用して 危険度を求め, 過去に発生した崩壊と比較, 検討を行っ た

\section{2. 集水モデルの作成}

\section{（1）地下水の集水モデル}

本報で提案する集水モデルは，川谷が提案した山地斜 面の地表流の流出解析モデルの考え方 ${ }^{6 !}$ を地下水の流れ に応用した手法である。このモデルは連続の式（1）上 ダルシー則の式（2），(3) よりなる.

$$
\begin{aligned}
& \lambda \frac{\partial h}{\partial t}+\frac{\partial q_{x}}{\partial x}+\frac{\partial q_{y}}{\partial y}=r \\
& q_{x}=h k I_{x} \cdots \cdots \cdots \cdots \cdots \cdots \\
& q_{y}=h k I_{y} \cdots \cdots \cdots \cdots \cdots \cdots \cdots \cdots \cdots
\end{aligned}
$$

ここで, $h$ : 見掛けの地下水位 $(\mathrm{m}), q$ : 単位時間当た りの単位幅流量 $\left(\mathrm{m}^{2} / \mathrm{h}\right), I$ : 動水勾配, $r$ : 有効降雨 (地

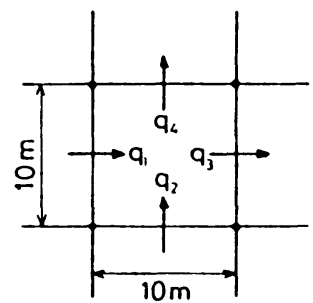

図一1 セルにおける地下水の流れ
下水位上昇に直接寄与する降雨) 強度 $(\mathrm{m} / \mathrm{h}), k$ : 透 水係数 $\left(\mathrm{m}^{2} / \mathrm{h}\right), \lambda$ : 有効間隙率であり, 添字 $x, y$ は それぞれの方向の成分を表わす。式（1)，（2），(3) より $h$ を求めるため図一1に示すように, 一辺が $10 \mathrm{~m}$ の正方形に分割されたセルを使用する. 時刻 $t$ におけ るセル中心の地下水位を $h^{(0)}$ ，時刻 $t+\Delta t$ における地下 水位を $h^{(1)}$ で表わすと式（1）より式（4）を得る.さ らに, $\Delta t$ を単位時間とすると式 ( 5 )，（6) が得られる.

$$
\begin{aligned}
& h^{(1)}=h^{(0)}+\frac{\left(q_{1}+q_{2}-q_{3}-q_{4}\right) \Delta t}{a \cdot \lambda}+\frac{r \cdot \Delta t}{\lambda} \\
& h^{(1)}=h^{(0)}+\frac{\left(q_{1}+q_{2}-q_{3}-q_{4}\right)}{a \cdot \lambda}+\frac{r}{\lambda} \ldots \ldots \ldots \ldots \ldots \ldots \ldots \ldots \ldots \ldots \ldots \ldots \ldots \ldots \ldots \ldots \ldots \ldots \ldots \ldots \ldots \ldots \ldots \ldots \ldots
\end{aligned}
$$

ここで, $q_{i}(i=1 \sim 4)$ は図一1に示すように各断面の単 位時間当たりの単位幅流量である. また $I_{i}(i=1 \sim 4)$ は 各方向の動水勾配， $a$ はメッシュ間隔である. 式 ( 5 ), （6）より各時間ごとの地下水位が求められる.

このモデルを用いて地下水位を求めるにあたって設定 した仮定は以下のとおりである。

1）有効降雨はすべて，ただちに基岩面に達し，地下 水面を形成する。

2) 式 (6) の地下水位 $h^{(0)}$ は, 時刻 $t$ でのセル中心 における水位とする。

3）本研究で対象とする表層崩壊はいずれも崩壊深が 1〜2 $\mathrm{m}$ であり, 格子の一辺の長さ $10 \mathrm{~m}$ に比してその値 が小さいため動水勾配 $I_{i}$ は隣接する各七ルの中心にお ける基岩標高より得られる基岩勾配とする.

4) 透水係数 $k$, 有効間隙率 $\lambda$, 有効降雨 $r$ はすべて のセルで一様とする.

5）一方向以上の流出を考えているため，透水係数の 大きさにより, 単位時間にセルから流出する流量が時刻 $t$ のときにセル内に貯留されている量を仮に越える場合 は, 各方向の流出量のあん分比例で流出させる.

\section{（2）モデルの妥当性についての検討}

上述したモデルより得られる結果が，はたして妥当な ものであるか否かをまず検討する必要がある。このよう な表土層中を流下する地下水の挙動に関する理論的アプ ローチとしては, 飯田が次のような考え方を提案してい
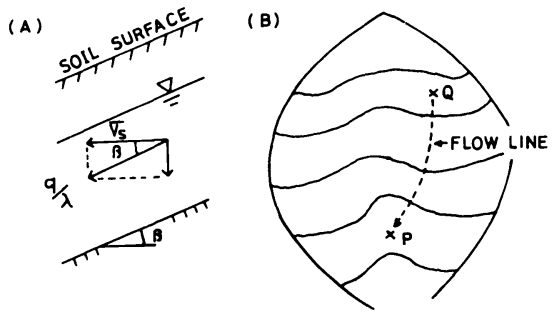

図一2 飽和中間流の模式図 ${ }^{7)}$ 
$る^{7 !}$.

斜面に平行な基岩上に発生した飽和中間流（本報の地 下水の流れと同意)がダルシー則を満たしながら流線(原 著では「落水線」と称している) に沿って斜面に平行に 流れると仮定すると, 水平方向の平均值の真の流速 $\bar{v}_{S}$ は図一2より次のように表わされる.

$$
\begin{aligned}
& q=k \sin \beta \cdots \cdots \ldots \ldots \ldots \ldots \\
& \bar{v}_{s}=(k / \lambda) \sin \beta \cdot \cos \beta \cdots
\end{aligned}
$$

ここで, $q$ : ダルシ一流速 $(\mathrm{m} / \mathrm{h}), k$ : 透水係数 $(\mathrm{m} / \mathrm{h})$, $\lambda$ : 有効間隙率, $\bar{v}_{s}$ : 水平方向の平均的な真の流速 $(\mathrm{m} / \mathrm{h})$ である、したがって，同じ流線上にある Q 点から $\mathrm{P}$ 点ま での飽和中間流の到達時間 $t_{P Q}$ は次のように表わされ る.

$$
t_{P Q}=\int_{P}^{Q} \frac{d s}{\bar{v}_{s}}=\frac{\lambda}{k} \int_{P}^{Q} \frac{d s}{\sin \beta \cdot \cos \beta}
$$

ここで積分は流線を水平面に投影した曲線に沿って行う ものとする．次に任意の地点において，等高線に平行な ある一定長さ $\Delta l$ のせを考えると，このせきを横切る 流線上にあって，しかもせきの上部に位置する各地点を 出発した水は, 式（9）で表わされるような時間でせき 地点に到達する。この到達時間 $t$ が一定となるような コンターを引けば，それより内部にある面積 $S$ が $t$ の 関数として決定されるが，それをさらに $\Delta l$ で除して， せきの単位長さ当たりの到達時間-面積曲線 $a(t)$ を彼 は定義した。
この $a(t)$ と単位幅当たりの流量 $Q(t)$ および水位 $H(t)$ との関係は, 特に, $t=0$ から有効降雨 $r$ が降り 続いた場合には次のようになる。ただし，降雨は瞬時に 表土層内を鈶直降下し，基岩面から飽和中間流を形成す るものとしている.

$$
\begin{aligned}
Q(t) & =r \cdot a(t) \cdots \ldots \ldots \ldots \\
H(t) & =\frac{r \cdot a(t)}{k \cdot \sin \beta \cdot \cos \beta}
\end{aligned}
$$

ここで理想斜面を設定して，斜面型の違いによる集水 性を評価すると次のようになる。一般に理想斜面は等高 線の曲率 $\varepsilon$ にっっ，その違いを特徵づけられる．流 線方向に傾斜 $\beta$ が一定で等高線が同心円状の斜面につ いて考え, せきの曲率を $\varepsilon$ とすると, $a(t), Q(t), H(t)$ はそれぞれ次式で示される。

$$
\begin{aligned}
& a(t)=\bar{v}_{s} \cdot t+(\varepsilon / 2) \bar{v}_{s}{ }^{2} t^{2} \cdots \\
& Q(t)=r \cdot \bar{v}_{s}\left\{t+(\varepsilon / 2) \bar{v}_{s} t^{2}\right\} \\
& H(t)=(r / \lambda)\left\{t+(\varepsilon / 2) \bar{v}_{s} t^{2}\right\}
\end{aligned}
$$

ここで $\bar{v}_{s}$ はいずれも式（8）で表わされるものとする. $\varepsilon$ は谷型斜面で正, 尾根型斜面で負の值をとり, $\varepsilon=0$ の場合は当然のことながら平行型斜面となる.

以上示した理論的アプローチによって，理想斜面では 地下水位の計算が可能となる.このため,この理想斜面 を数值地形モデル化し，前節で示したモデルにより近似 解を求め, 理論解と比較することによりモデルの妥当性 について検討を行う. 図一 3,4 はこの目的のために設

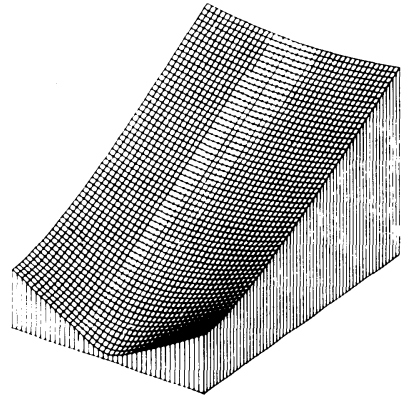

図-3 谷型斜面のブロックダイヤグラム

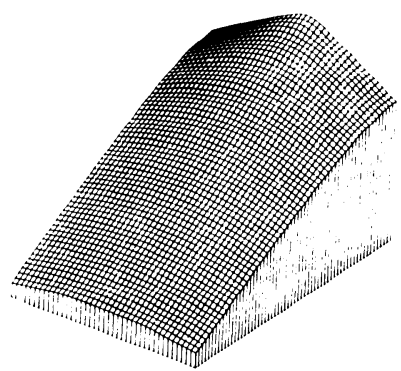

図-4 尾根型斜面のブロックダイヤグラム

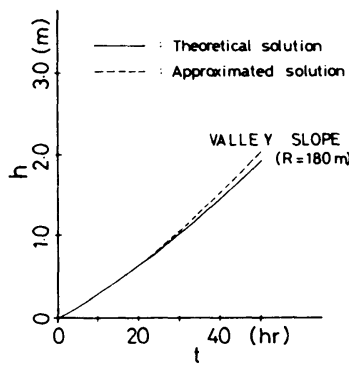

（a）谷型斜面 $(R=180 \mathrm{~m})$

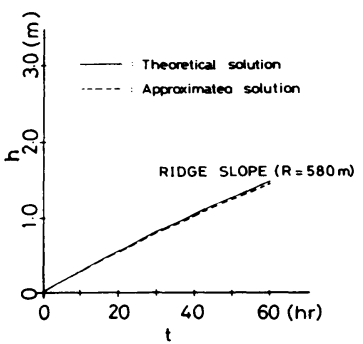

（c）尾根型斜面 $(R=580 \mathrm{~m})$

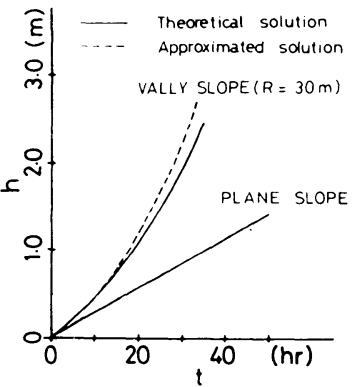

（b）谷型斜面 $(R=30 \mathrm{~m})$ および平行型 斜面

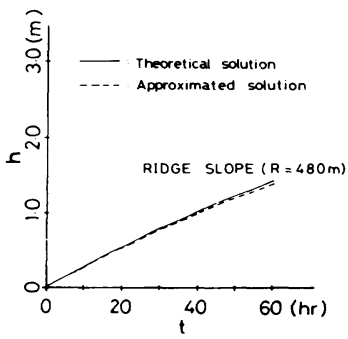

(d) 尾根型斜面 $(R=480 \mathrm{~m})$ 
定した谷型, 尾根型斜面のブロックダイヤグラムである. これらのブロックは $10 \mathrm{~m}$ 格子間隔とした。この理想斜 面に $r=0.01 \mathrm{~m} / \mathrm{h}, k=2.0 \mathrm{~m} / \mathrm{h}, \lambda=0.35, \beta=30^{\circ}$ を 与えた. 図一 5 は理論解と近似解の結果を示したもので ある。これらの結果から，集水モデルによる地下水位の 近似解は理論解と比較して, 平行型斜面では等しいが, 谷型斜面ではやや大きな値となり，尾根型斜面ではわず かに小さな值となることがわかる．これはメッシュ化す ることにより流下方向が限定されてくるために生じるも のと思われる．しかし，現実に山腹斜面上に分布する潜 在崩土層厚は $1.5 \mathrm{~m}$ 前後であることを考慮すると, こ の程度までは近似解でも理論解をほぼ等しく表わすこと ができるとみなせる．よって本報ではこの集水モデルを 使用するものとする．このモデルの特徵としては，理論 的アプローチを自然斜面に適用する場合には自然斜面は さまざまな曲率を示すため容易にその解を求めることは 困難であるのに対して，この集水モデルは地形を数值モ デル化しているためどのような曲率を示す斜面にも適用 が可能である利点を有していることである.

\section{3. 無限長斜面安定解析モデル}

本報で対象としている表層崩壊は，六甲山系で 1967 年に発生した崩壊を例にとれば平均的規模は, 長さ 14 $\mathrm{m}$, 幅 $9 \mathrm{~m}$, 深さ $1 \mathrm{~m}$ 程度のものであり ${ }^{8)}$, 長さに比し て深さが非常に浅いもので，すべり面も直線的なものが 多いことがその特徵である。このため, 花崗岩地域の表 層崩壊の安定解析にはしばしば無限長斜面の安定解析が よく用いられている9!.

しかし，自然斜面は決して無限長ではなく，表土層の 厚さも一様でないため崩壊発生位置およびその規模（長 さ）を予知する場合にはこの手法は不適であり，これに 代わるものとして沖村はかつて多平面安定解析法を提案 した . しかし，本報のように $10 \mathrm{~m} \times 10 \mathrm{~m}$ のセルを対 象として，この限られた空間内のセルの安定およびセル 間の安定度を比較する場合には，このセル内では表土層 厚や傾斜を一様と仮定できるものとみなして，本報では 各セルに無限長斜面安定解析式を適用することにより各 七ルの安全率を求めた。したがってこの解析から得られ る結果の精度は必ずしも良好なものではないかもしれな いが，危険度を七ル間で相対的にみるには十分な手法と 考えられる。

Simons らは, 自然斜面における崩壊 (landslide) の 危険度を評価する無限長斜面安定解析モデルとして次式 を提案している ${ }^{10}$ (図一6参照)。

$$
\begin{aligned}
& S F=\frac{c_{s}+c_{r}+A \cdot \cos ^{2} \beta \cdot \tan \phi}{B \cdot \sin \beta \cdot \cos \beta} \ldots . \\
& A=q_{0}+\left(\gamma_{s a t}-\gamma_{w}\right)(h-z)+\gamma_{t}(H-h)
\end{aligned}
$$

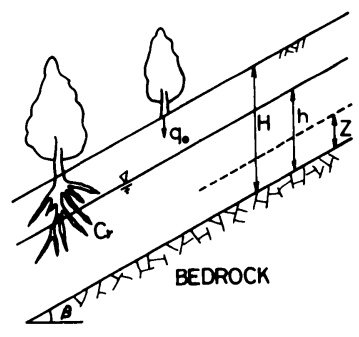

図一6 無限長斜面のモデル10)

$$
B=q_{0}+\gamma_{s a t}(h-z)+\gamma_{t}(H-h)
$$
ここで, $S F$ : 安全率, $c_{s}$ : 土の粘着力 $\left(\mathrm{tf} / \mathrm{m}^{2}\right), c_{r}$ : 根系による粘着力 $\left(\mathrm{tf} / \mathrm{m}^{2}\right), \phi:$ 土の内部摩擦角 (度), $\gamma_{s a t}$ : 土の飽和単位体積重量 $\left(\mathrm{tf} / \mathrm{m}^{3}\right), \gamma_{t}$ : 土の湿潤単位 体積重量 $\left(\mathrm{tf} / \mathrm{m}^{3}\right), \gamma_{w}$ : 水の単位体積重量 $\left(\mathrm{tf} / \mathrm{m}^{3}\right), H$ : 基岩面加の表土層厚 $(\mathrm{m}), h$ : 基岩面からの地下水 位 $(\mathrm{m}), z$ : 基岩面からすべり面までの高さ $(\mathrm{m}$ ，ただ し $0 \leqq z \leqq h), \beta$ : 斜面（基岩）勾配 (度)， $q_{0}$ ：植生に よる上載荷重 $\left(\mathrm{tf} / \mathrm{m}^{2}\right)$ である。

本研究においてはすべり面は基岩に沿った潜在すべり 面で発生すると仮定しているため $z=0$ である．植生に よる.上載荷重 $q_{0}$ は現在では不明であるため，これもゼ 口と仮定する． $h$ は集水モデルによって時間ごとに地下 水位が求められるため, これを $h(t)$ と仮定すると, 式 (15) の安全率 $S F$ も時間の関数となり, 次式で表 わされる。

$$
\begin{aligned}
& S F(t)=\frac{c_{s}+c_{r}+A(t) \cos ^{2} \beta \cdot \tan \phi}{B(t) \sin \beta \cdot \cos \beta} \\
& A(t)=\left(\gamma_{s a t}-\gamma_{w}\right) h(t)+\gamma_{t}(H-h(t)) \cdots \cdots \\
& B(t)=\gamma_{s a t} h(t)+\gamma_{t}(H-h(t)) \cdots \cdots \cdots \cdots \cdots
\end{aligned}
$$

本報では式（18）を用いて各セルの安全率を求めること にする．次に式（18）に代入するそれぞれの值の決定方 法について述べる。

1）各セルにおける表土層厚 $(H)$

表土層厚は $10 \mathrm{~m}$ 間隔で設定した格子点の表土層厚 $\left(H_{G}\right)$ として入力する. 各セルの表土層厚 $(H)$ は， それぞれのセルを構成する 4 点の $H_{G}$ の平均值とした. 各 $H_{G}$ はそれを詳細な現地調査で計測することは困難で あるため，本報では空中写真および現地調査で明らかに 表土層が存在しないと判定された格子点ではゼロとし, その他の格子点では一様の厚さで分布しているものと仮 定し，本報では $1.2 \mathrm{~m}$ とした。なお，比較対象として $1.6 \mathrm{~m}$ での計算も行った.

2) 各セルにおける傾斜 $(\beta)$

各セルの傾斜 $(\beta)$ は，各セルを構成する 4 格子点の 斜面標高加格子点の表土層厚 $\left(H_{G}\right)$ を引いた格子点 の基岩標高 $z_{i}(i=1 \sim 4)$ を用いて, 一次の回帰式によ 


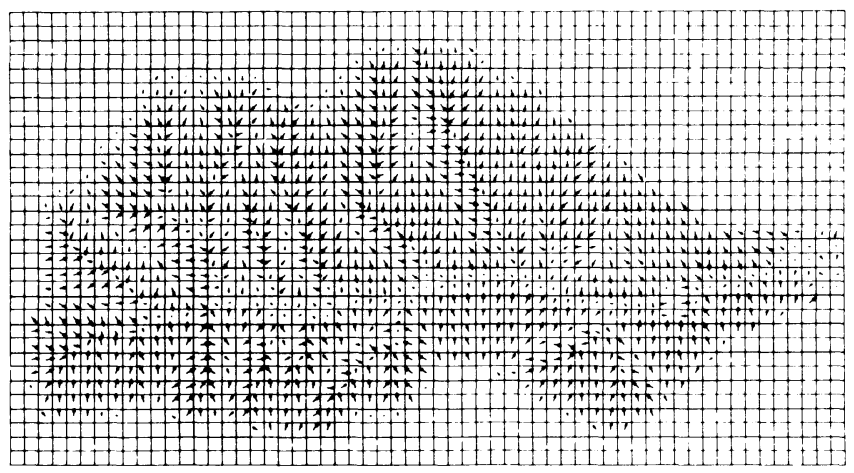

図一7 各セルの基岩勾眍とその方向の分布図

る平面近似 ${ }^{11}$ を行い, その最大方向の傾斜を使用した. 式 (21) は平面の方程式で, $z$ は各セルの $x, y$ 点にお ける基岩標高で, $b_{i}, b_{2}, b_{3}$ は係数である.

$z=b_{1}+b_{2} x+b_{3} y$

ここで

$$
\left(\begin{array}{l}
b_{1} \\
b_{2} \\
b_{3}
\end{array}\right)=\left(\begin{array}{ccc}
n & \sum x & \sum y \\
\sum x & \sum x^{2} & \sum x y \\
\sum y & \sum x y & \sum y^{2}
\end{array}\right)^{-1}\left(\begin{array}{c}
\Sigma z \\
\sum x z \\
\sum y z
\end{array}\right)
$$

式 (22) の $n$ はデー夕数で, 本報の場合は $n=4$ である. 図一7はこの方法によって得られた竹平 NW 試験地の 傾斜分布図を示す。これらは各セルにおける平面の単位 法線ベクトルの $x^{-} y$ 平面（水平面）への投影長および その方向を示している. これは本試験地の水系分布をよ く示しており，この方法でセルの傾斜を表示できるもの とした。

3）土質工学的諸量 $\left(c_{s}, \phi, \gamma_{t}, \gamma_{s a t}, \gamma_{w}, \lambda, k\right)$

これらの量は土質試験により得られる值である.これ らの值は各花崗岩地域ですでにいくつかの調査が行われ ているが, 本報では $c_{s}=0.5 \mathrm{tf} / \mathrm{m}^{2}, \tan \phi=0.6, \gamma_{t}=$ $1.7 \mathrm{tf} / \mathrm{m}^{3}, \quad \gamma_{\text {sat }}=1.9 \mathrm{tf} / \mathrm{m}^{3}, \quad \gamma_{w}=1.0 \mathrm{tf} / \mathrm{m}^{3}, \lambda=0.35, \quad k$ $=2.0 \mathrm{~m} / \mathrm{h}$ とした（これらの值は本試験地におけるデー 夕 $^{12)}$ およ゙花崗岩地域においてすでに得られたデータ ${ }^{13)}$ より仮定した).

4) 根系による粘着力 $\left(c_{r}\right)$

根系による粘着力は土㙵緊縛による土壌せん断抵抗力 補強という斜面安定化にとってはプラスの効果を与える ものと考えられている(4). しかし，これを求める手法は いまだ開発されておらず，この値を求めることは現状で は不可能である.このため本手法では,この未知の值を 以下に述べるような補正量としてこの要因を使用した。

降雨のない初期状態 (地下水位のない状態) で上述し た数值を用いて各セルで無限長斜面安定解析を行えば, この状態では崩壊が発生しないであろうにもかかわら ず, 安全率 $\left(S F_{0}\right)$ が 1.0 を下回るセルが現われる場合
があった（本報では $H_{G}=1.6 \mathrm{~m}$ と仮定した場合に少し 現われた)。これは現実とは一致しない。このような結 果が現われた理由としては, 各格子点の表土層厚の設定 時に, 基岩が露頭している場所はゼロで他は一様と与え たためであると考えられる. 本報では $S F_{0}$ を 1.05 以上 の值にして, 地下水位のない状態では崩壊が発生し得な いようにするため, $H_{G}=1.6 \mathrm{~m}$ と仮定した場合のみこの $c_{r}$ を補正量として流域内に一様に与え, $H_{G}=1.2 \mathrm{~m}$ の 場合はゼロとした。このため, 本報においては根系によ る粘着力を評価したというよりむしろ仮定に起因する解 の予盾点を補正するための量とした.この根系による粘 着力は各格子点の $H_{G}$ がすべて計測された後に新たに議 論する必要がある.

5）表土層内の地下水位 $(h(t))$

表土層内の地下水位 $(h(t))$ は前節で述べた集水モ デルで得られる值を用いた。ただし，この集水モデルで 得られる地下水位が表土層厚を越えた場合は, その水位 はただちに地表流として流下し，地表水深は出現しない ものと仮定する.

以上述べた各数值を用い, 対象試験地に有効降雨を与 えて時間ごとの安全率 $S F(t)$ を計算する.

\section{4. 崩壊危険予測図の作成}

研究対象地域である竹平 $N W$ 試験地において, 前節 で定義した無限長斜面安定解析モデルを用いて得られる 安全率 $(S F(t))$ によって崩壊危険予測図を作成する.

解析に用いた降雨条件は有効降雨 $r=20 \mathrm{~mm} / \mathrm{h}$ を 50 時間一様に与えた.このように一様降雨を与えた理由は, （1）将来の降雨パターンを予知できない，（2）本報は 雨水の鉛直浸透過程を考慮していないため, 仮に過去の 降雨を入力しても得られる結果（特に崩壊発生時刻）の 信頼性にそしい,（３）過去の降雨のうちどれだけが有 効降雨となるのか現在では不明である，（4）過去の降 雨はそのときに発生した崩壊の理由を説明し得ても, 将 
来の予知には役に立たない，等のためである.

以上のような条件で得られる $S F(t)$ を用いた危険 度の表示は, 各セルの $S F(t)$ が 1.0 を下回るに必要 な降雨継続時間 $\left(t_{c r}\right)$ を指標として評価した。この理 由は，危険度の高い斜面ほどより短い降雨継続時間で崩 壊が出現するであろうと考えられるからである，具体的 な危険度の設定は以下のように行った。
$\mathrm{A}: 0<t_{\mathrm{cr}} \leqq 10(\mathrm{~h})$
$\mathrm{B}: 10<t_{c r} \leqq 20(")$
C $: 20<t_{c r} \leqq 30 \quad$ (")
$\mathrm{D}: 30<t_{c r} \leqq 40 \quad(")$
$\mathrm{E}: 40<t_{c r} \leqq 50$ (")

以上の定義により得られる崩壊危険度予測図を図一8, 図一 9 に示す. 図一8 は $H_{G}=1.2 \mathrm{~m}$ と仮定した場合, 図 一9 は $H_{G}=1.6 \mathrm{~m}$ と仮定した場合の結果である.この図 中の太線で囲まれている部分は, 1972 年の豪雨によっ て発生した崩壊源（副次崩壊を除く）が現われたセルを 示したものである.これより図一8，図一 9 ともすべて の崩壊源内で A あいはBの危険度の高いセルが出現し ていることがわかり，このような手法によっても崩壊発 生の危険度の高い場所を予知できることがわかる．しか し, 図一8, 図一9ともランキングされた各セルの大部

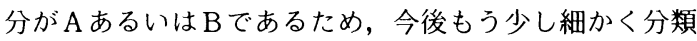
する必要があるかもしれない。

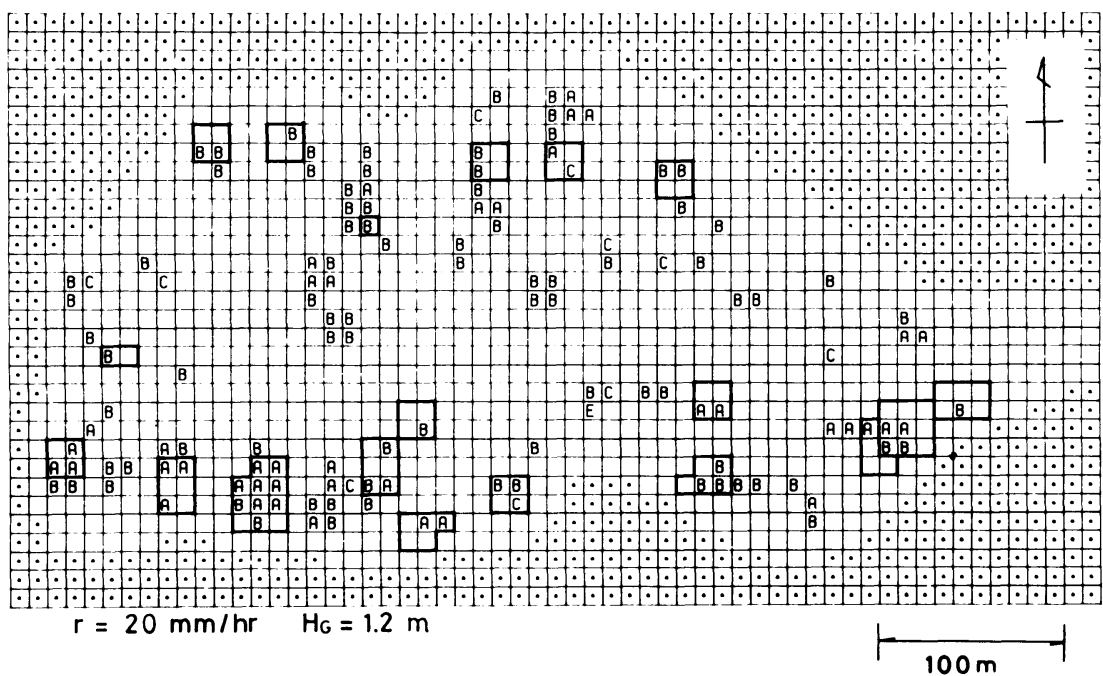

図一8 表首崩轅危険予測図 (竹平 NW 地区, $H_{G}=1.2 \mathrm{~m}$ )

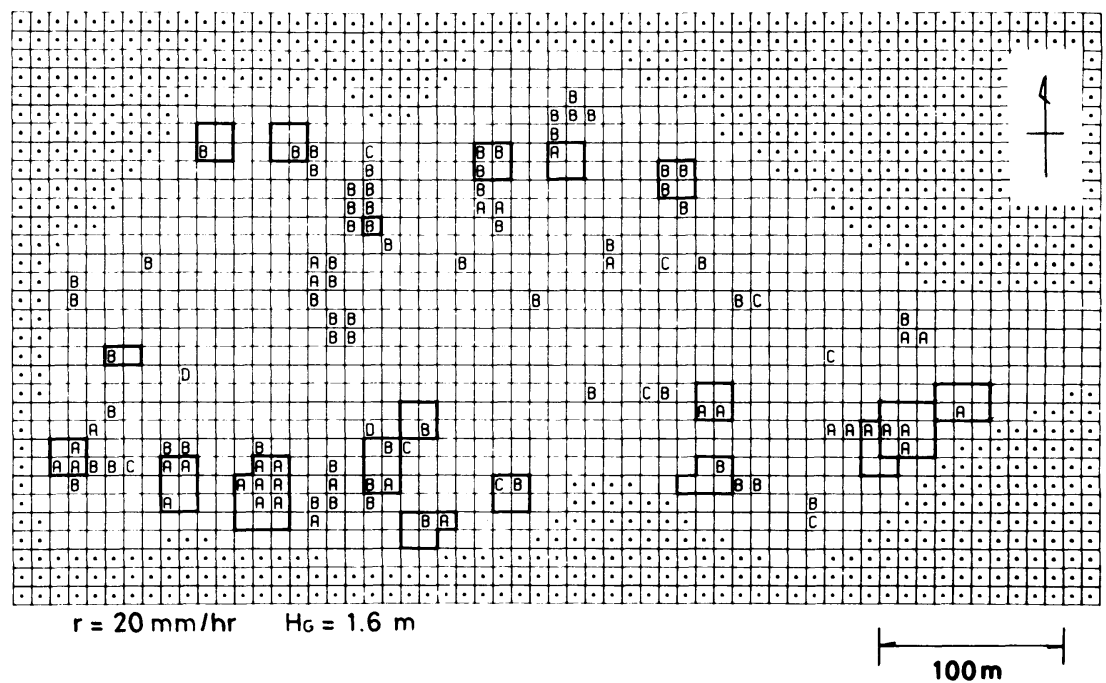

図一9 表屋崩垻危険予測図 (竹平 NW 地区, $H_{G}=1.6 \mathrm{~m}$ ) 
図一8, 図一9を比較すると危険度の高い斜面はほぼ 同じ位置に現われていることがわかる.しかし， $H_{G}=$ $1.2 \mathrm{~m}$ の方が $H_{G}=1.6 \mathrm{~m}$ と仮定した場合に比して危険セ ルが幾分多いめに現われている.これは前節で述べたよ うに, 後者の場合, 補正值 $c_{r}$ を与えた影響によるもの と思われる.

\section{5. 結論}

本報では表層崩壊の発生に影響を及ぼすと考えられる 要因のうち，集水面積の代わりに斜面の三次元的な立地 条件を評価した集水性の概念を導入することにより，三 要因を同時に評価した崩壊危険度を予測する手法を提案 した。その結果は, 過去の崩壊発生位置を危険度の高い レベルで予知しており，本手法が有用であることが推定 された.

本手法が有している特徴は以下のとおりである.

（1）調査地域内のすべての斜面を対象として，その 危険度が統計的または経験的な結果としてではなく，解 析的に評価できる.

（2）空間に分布する地形特性を三次元的に評価して いる.

（3）コンピュータによって危険度を評価しているた め, 解析は迅速, 正確に行える.

（4）入力情報はセルごとに入力できるため，将来， 詳細な調查により新たな情報が得られれば，この值を容 易に採用でき, 予知精度を向上させることができる.

（５）素因のみならず誘因である降雨条件を考慮に入 れることができる.

一方，この手法の問題点としては次のことが考えられ る.

（1）各セルでの危険度は評価できても, 結果として 発生する崩壊の規模を求めることができない.

（2）危険度を設定する際に仮定した有効降雨強度 $r$ と危険度判別のための降雨継続時間 $t_{c r}$ は今後さらに 検討を要する.

（3）降雨から浸透を経て, 地下水面の形成に至るプ ロセスを今後評価する必要がある.

（4）格子点の表土層厚を今後測定し, 他の要因の評 価およびそれらの仮定值をさらに検討する必要がある.
謝辞：本研究を進めるにあたっては, 神戸大学工 学部川谷 健教授より多くのご教示をいただいた。こ こに深く謝意を表します。なお，本研究は昭和 58 年度 科学研究費自然災害特別研究 (2)（研究代表者：沖村 孝，58025034）の成果の一部であることを申し添え，記 して謝意を表します.

\section{参 考 文 献}

1)沖村孝・田中茂：一試験地における風化花こう岩の 土層構造と崩壊発生深さに関する研究, 新砂防, 116, pp. $7 \sim 16,1980$.

2) 沖村 孝: 山腹表層崩壊発生位置の予知に関する一研究, 土木学会論文報告集, 331, pp. 113 120, 1983.

3）羽田野誠一：崩壊性地形（その 2 ), 土と基礎, 22-11, pp. 85 93, 1974.

4) 沖村 孝：地形要因を利用した豪雨による山腹崩壊発生 位置の予知システムについて, 土木学会論文報告集, 338 , pp. $131 \sim 138,1983$.

5）沖村 孝・市川龍平：数値地形モデルより得られる地形 的滑動力示数による表層崩壊危険斜面の予知, 神戸大学 工学部土地造成工学研究施設報告, 2, pp. 17 32, 1984.

6) 川谷 健：地形変化と降雨流出, 地形, 2-1, pp. 67 72, 1981.

7）飯田智之：飽和中間流に対する斜面形状の効果の評価法, 地形, 5-1, pp. 1 12, 1984.

8) Okimura, T. : Rapid Mass Movement and Groundwater Level Movement, Zeitschrift für Geomorphologie, Suppl. -Bd. 46, pp. 35 54, 1983.

9）た之えば, 渡 正亮・中村浩之：花崗岩風化地帯におけ るがけくずれについて, 防災科学技術総合研究報告, 24 , pp. $127 \sim 139,1970$.

10) Simons, D. B. et al. : Mapping of Potential Landslide Areas in terms of Slope Stability, USDA Forest Service Rocky Mountain Forest and Range Experiment Station, 75 p. , 1978.

11) Davis, J. C. : Statistics and Data Analysis in Geology, John Wiley, 550 p., 1973.

12）藤井郁也：安定解析による豪雨時表層崩壊予測の基礎的 研究, 神戸大学大学院工学研究科修士論文, 67 p., 1984.

13）沖村 孝：潜在崩土層分布を利用した表層崩壊発生位置 に関する研究, 新砂防, 124, pp. $9 \sim 18,1982$.

14）秋谷孝一：豪雨時における自然斜面の安定（崩壊の素因 として, 植生特に森林), 豪雨時における自然斜面の安定 に関するシンポジゥム, pp. 33〜38, 1978.

(1984.7.4 · 受付) 